\title{
Influence of Using Floor Jets on the Local Scour Downstream Fayoum Type Weir
}

\author{
Gamal Elsaeed ${ }^{1}$, Abdelazim M. Ali ${ }^{2}$, Alaa Nabil El-Hazek³ ${ }^{3}$ Ahmed M. M. Ibraheem,** \\ ${ }^{1}$ Faculty of Engineering at Shoubra, Benha University \\ Cairo, Egypt \\ ${ }^{2}$ Hydraulics Research Institute, National Water Research Center, Ministry of Water Resources and Irrigation \\ Cairo, Egypt \\ ${ }^{3}$ Faculty of Engineering at Shoubra, Benha University \\ Cairo, Egypt \\ ${ }^{4}$ Hydraulics Research Institute, National Water Research Center, Ministry of Water Resources and Irrigation \\ Cairo, Egypt \\ *Corresponding author's email: eng.ahmedmahmoud2009 [AT] yahoo.com
}

\begin{abstract}
Local scour downstream hydraulic structures may cause damage or complete failure of these structures. In this paper, an experimental study was carried out to investigate using floor water jets as a mitigation measure to minimize the local scour downstream stilling basin and to clarify the best arrangement of these jets. Different cases were established during this study including different flow discharges, tail water depths and floor jet locations. A base case without using water jets was included to estimate the influence of using suggested water jets arrangements. Additional four cases for various jets arrangements were established and studied. Obtained results were analyzed and graphically presented. The optimum design was easy to be used for increasing the performance of stilling basin. The results indicated that the optimal arrangement of floor jets was the case $(D)$, where the last three rows of floor jets were used. This optimum design results in a reduction in maximum scour depth ranged from $44.53 \%$ to $76.15 \%$ and reduction in scour length ranged from $25.00 \%$ to $71.93 \%$ compared to the base case.
\end{abstract}

Keywords— Floor Jets, Scour, Silting, Stilling Basin, Weirs.

\section{INTRODUCTION}

The cost of protection layer downstream stilling basin can be reduced by using suitable appurtenances to dissipate energy in an efficient way. Conducting any hydraulic energy dissipators depends on expending a part of the energy of high flow velocity by boundary shear stress. Floor jets will be helpful in deflecting the flow away from the canal bed. Chute blocks, baffle piers and end sills could be employed, Edward [1] and Peterka [2], to dissipate energy, stabilizing the flow, increasing the turbulence, and distributing the velocities evenly through the basin. Thulfikar et al., [3] studied the design and use of inclined weirs with $120^{\circ}$ angles for the alleviation of scour around hydraulic structures. E.A. Elnikhely [4] carried out a physical model that concluded that the case of staggered cylinder blocks over sloped spillway achieved the smallest values of scour and deposition parameters. Gamal M. Abdel Aal, et al., [5] deduced that the stepped spillway with breakers type had dissipated more energy than the classical stepped spillway type. Akram Abbaspour, et al., [6] concluded that using two buried plates at the distances of 30 and $45 \mathrm{~cm}$ from the non-erodible bed was more effective in reducing the scour depth than using single buried plate. M. M. Ibrahim, [7] studied experimentally the influence of sharp crested weir with orifices and illustrated that a weir with nine orifices exhibited the highest performance from the perspective of minimizing the bed topography. Seungho Hong, et al., [8] presented an experimental study for the performance of a spillway structure on the Kissimmee River, operated under critical conditions of drought and flooding with accompanying low and high tailwater depths for both gate-controlled and uncontrolled 
spillway flow conditions. Mohammad, [9] demonstrated the influence of classical V-notch weir and a compound sharp crested weir consisting of two triangular parts with different notch angles. Using the compound V-notch weir to pass high discharges instead of the classical V-notch weir was recommended. Ahmed, [10] studied experimentally the influence of double lines of water jets on minimizing the scour-hole dimensions downstream of a Fayoum type weir. The results showed that the relations $\left(\mathrm{L}_{j} / \mathrm{L}_{\mathrm{f}}=0.7\right)$ and $\left(\mathrm{Q}_{\mathrm{j}} / \mathrm{Q}=0.15\right)$ achieved a maximum reduction $(5 \%: 68 \%)$ in the scour depth values and also a reduction $(49 \%$ $: 76 \%)$ in the scour length. Where, $\mathrm{Lj}$ : the length from the weir toe to the center of water jet lines, $\mathrm{L}_{\mathrm{f}}$ : the total floor length, $\mathrm{Q}_{\mathrm{j}}$ : jet discharge, and Q: the flow discharge. Hossam, et al., [11] demonstrated that using spaced triangular corrugated aprons reduced the scour depth and length of fine sand by $63.4 \%: 30.2 \%$, and by $44.2 \%: 20.6 \%$ for coarse sand in comparing with classical jump. Esam, [12] indicated that using a single line of floor water jets achieved $50 \%: 90 \%$ reduction in maximum scour depth and $42 \%: 85 \%$ reduction in scour hole length compared to the case of floor without water jets. Fahmy, [13] carried out an experimental study to predict the scour geometry downstream Fayoum type weir and to minimize the scour using a row of semi-circular baffle blocks. The results concluded that using distance between baffle lines and the weir toe related to the floor length $\left(\mathrm{L}_{\mathrm{b}} / \mathrm{L}_{\mathrm{f}}=0.4\right)$ and baffle's height related to outer baffle's diameter $\left(\mathrm{H}_{\mathrm{b}} / \mathrm{D}_{\mathrm{o}}=1.33\right)$ achieved the maximum reduction in the scour length that ranged from $77.06 \%$ to $93.66 \%$. M.C. Tuna, et al., [14] illustrated that step geometry, stepped chute angle, downstream water level and sill types of a stilling basin were very important parameters for the geometry of the scour hole. Dehghani, et al., [15] investigated experimentally the scour characteristics of scour hole downstream of combined free over weir and below gate.

\section{Nomenclature}

\begin{tabular}{|c|c|c|c|c|c|}
\hline Symbol & Description & Units & Symbol & Description & Units \\
\hline$d_{s}$ & the maximum scour depth & $\mathrm{m}$ & $\mathrm{L}_{\mathrm{j}}$ & $\begin{array}{l}\text { the distance from the weir toe to } \\
\text { the center of water jet lines }\end{array}$ & $\mathrm{m}$ \\
\hline $\mathrm{L}_{\mathrm{s}}$ & the maximum scour length & $\mathrm{m}$ & $\mathrm{L}_{\mathrm{b}}$ & $\begin{array}{l}\text { Distance from weir toe to the end } \\
\text { of stilling basin }\end{array}$ & $\mathrm{m}$ \\
\hline B & flume width & $\mathrm{m}$ & $\mathrm{S}$ & the distance between jets & $\mathrm{m}$ \\
\hline $\mathrm{B}$ & weir width & $\mathrm{m}$ & $\mathrm{S}_{\mathrm{o}}$ & the bed slope & $\mathrm{m}$ \\
\hline $\mathrm{d}$ & the jet pipe diameter & $\mathrm{m}$ & $\mathrm{V}$ & the mean flow velocity & $\mathrm{m} / \mathrm{s}$ \\
\hline $\mathrm{d}_{50}$ & the mean particle diameter & $\mathrm{m}$ & $\mathrm{V}_{\mathrm{j}}$ & the jet flow velocity & $\mathrm{m} / \mathrm{s}$ \\
\hline $\mathrm{h}$ & the weir operating head & $\mathrm{m}$ & $\mathrm{y}_{\mathrm{t}}$ & the tail water depth & $\mathrm{m}$ \\
\hline $\mathrm{g}$ & the gravitational acceleration & $\mathrm{m} / \mathrm{s}^{2}$ & $\rho$ & water mass density & $\mathrm{kg} / \mathrm{m}^{3}$ \\
\hline $\mathrm{L}_{\mathrm{f}}$ & the bed material length & $\mathrm{m}$ & $\rho_{\mathrm{s}}$ & soil particle density & $\mathrm{kg} / \mathrm{m}^{3}$ \\
\hline $\mathrm{L}_{\mathrm{p}}$ & distance between water jet rows & $\mathrm{m}$ & $\mu$ & water dynamic viscosity & $\mathrm{kg} / \mathrm{m} . \mathrm{s}$ \\
\hline $\mathrm{L}_{\mathrm{r}}$ & $\begin{array}{l}\text { Distance from end of stilling } \\
\text { basin and scour measured points }\end{array}$ & $\mathrm{m}$ & $\mathrm{N}$ & number of floor jet rows & --- \\
\hline$\frac{d s}{y t}$ & Dimensionless of scour depth & --- & & & \\
\hline
\end{tabular}

\section{EXPERIMENTAL SETUP}

Figure 1 shows a definition sketch of the involved phenomenon and indicates the related parameters. The experimental study was carried out at the hydraulic laboratory of the Hydraulics Research Institute (HRI), National Water Research Center (NWRC), Ministry of Water Resources and Irrigation (MWRI), Egypt. Physical model of Fayoum type weir is used to study the efficiency of using water jet to enhance the stilling base function, also the model including stilling basin and five lines of water jets. Each line is located at $0.4 \mathrm{~m}$ downstream weir toe. 


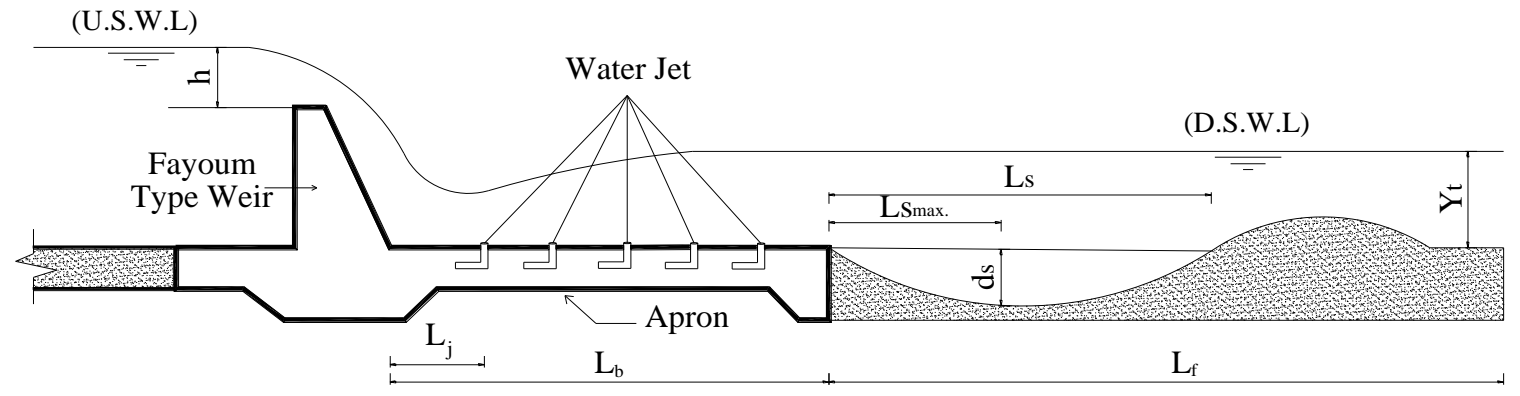

Figure 1 Definition Sketch of the Experimental Setup

The model structure is made from plexiglass material in steel frame walled flume of $26.0 \mathrm{~m}$ long, $1.0 \mathrm{~m}$ wide, and $1.2 \mathrm{~m}$ deep. The glass panels allow visual investigation and photo documentation of the flow patterns and bed configurations. A Fayoum type weir is made of galvanized steel sheet with $2 \mathrm{~mm}$ thickness. The weir has $0.1 \mathrm{~m}$ crest width, $1.0 \mathrm{~m}$ crest length, $0.5 \mathrm{~m}$ height, and slope of 1:2. The model contains $3.6 \mathrm{~m}$ stilling basin $(2.4 \mathrm{~m}$ downstream the weir toe, $0.35 \mathrm{~m}$ under the weir, and $0.85 \mathrm{~m}$ upstream the weir). The movable bed downstream stilling basin is simulated by sand material with $\mathrm{d}_{50}=0.423 \mathrm{~mm}$, length of $5.0 \mathrm{~m}$, and thickness of $0.30 \mathrm{~m}$, as illustrated in Figure 2.

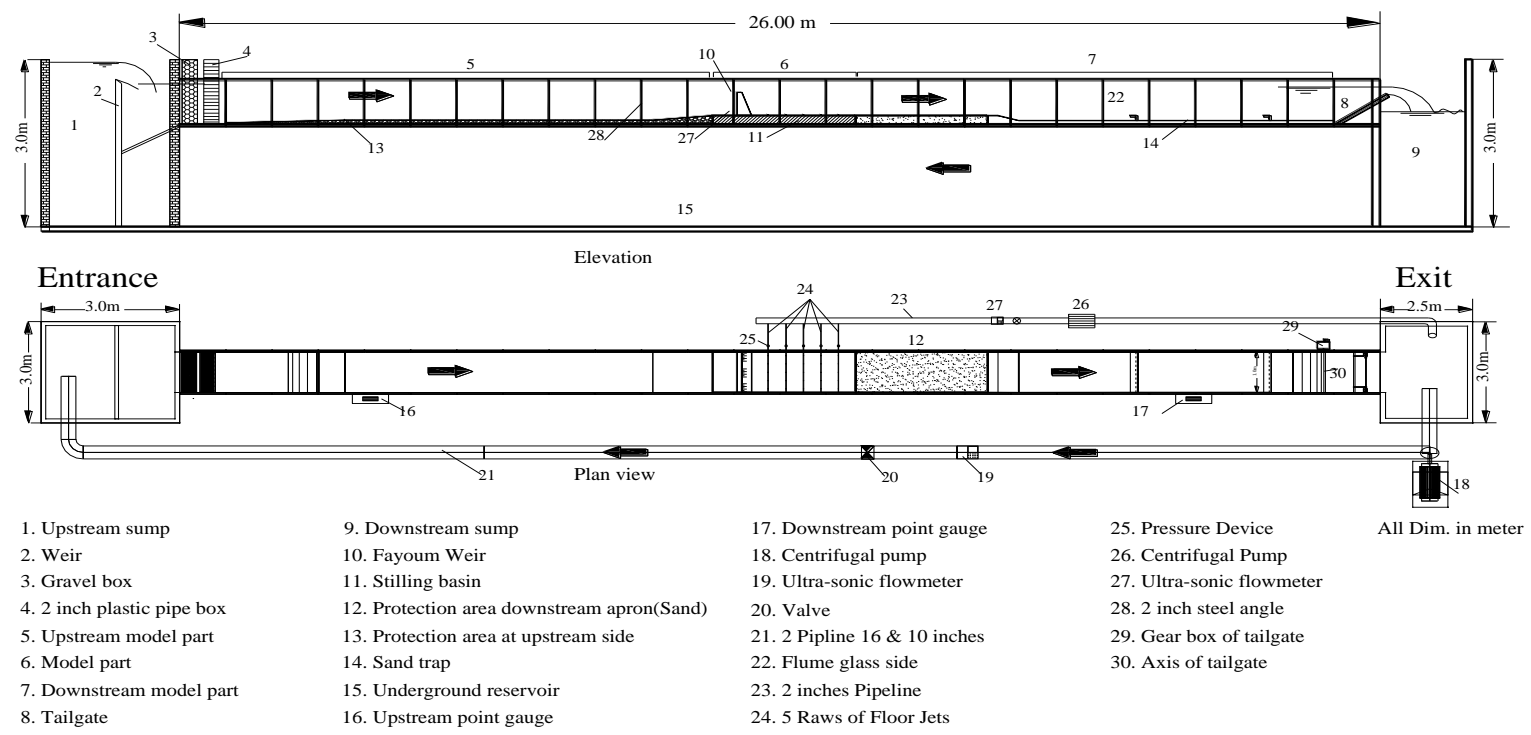

Figure 2 Details of the Flume and Model Arrangement

\section{MODEL RUNS}

Forty-five experimental runs were carried out simulating nine flow conditions of three discharges $(120,150$ and $180 \mathrm{~L} / \mathrm{s})$ and three tail water depths $(20,25$ and $30 \mathrm{~cm})$ using four different designs of stilling basin according to arrangement of floor jet rows. In addition to the design without water jets, which was considered as a base case, as shown in Table 1 . The experiments were designed to vary the independent variables of flow discharge, tail water depth and location of utilized floor jet rows. The velocity profiles components were measured at the centerline, at five point depths for each profile $0.2,0.4,0.6,0.8$ and 0.9 from the water depth, and the scour downstream the apron was measured using mesh with $0.25 \mathrm{~m}$, as shown in Figure 3. 
Table 1 Experimental Cases for Test Runs

\begin{tabular}{|c|c|c|c|c|c|}
\hline \multirow{2}{*}{ Case } & \multicolumn{5}{|c|}{ Rows No. } \\
\cline { 2 - 6 } & 1 & 2 & 3 & 4 & 5 \\
\hline A & X & X & X & X & X \\
\hline B & $\sqrt{ }$ & $\sqrt{ }$ & $\sqrt{ }$ & $\sqrt{ }$ & $\sqrt{ }$ \\
\hline C & $\sqrt{ }$ & $\sqrt{ }$ & $\sqrt{ }$ & $X$ & X \\
\hline D & $X$ & $X$ & $\sqrt{ }$ & $\sqrt{ }$ & $\sqrt{ }$ \\
\hline E & $\sqrt{ }$ & $X$ & $\sqrt{ }$ & $X$ & $\sqrt{ }$ \\
\hline \multicolumn{7}{|c|}{ X: Cloned } \\
\hline
\end{tabular}

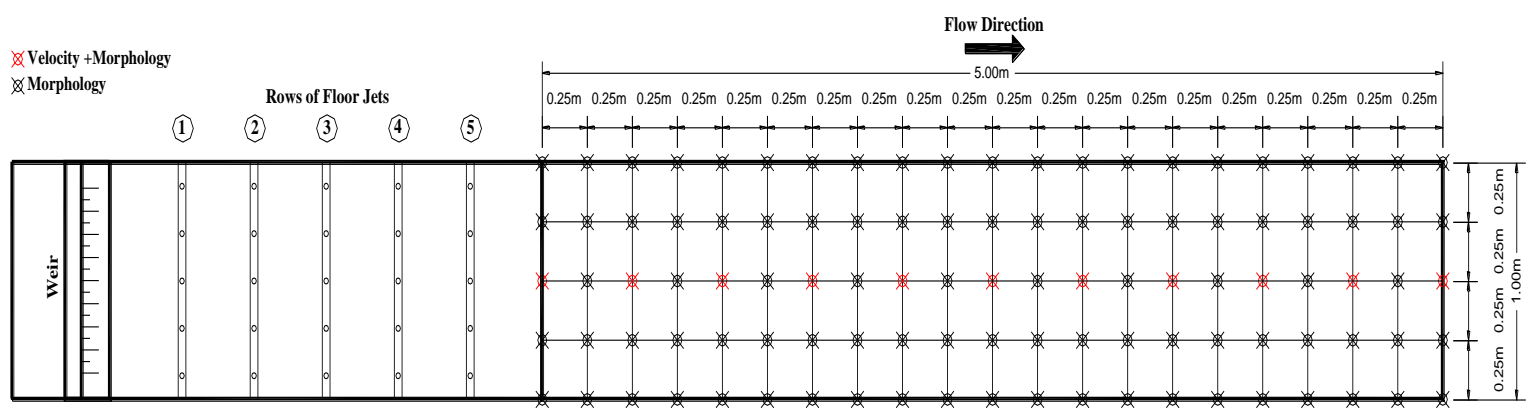

Figure 3 Locations of Velocity Profiles and Bed Morphology Measuring Points

\section{REULTS AND DISCUSSION}

Figure 4 presented the velocity distribution downstream stilling basin with different cases of floor jet rows at high flow condition $(\mathrm{Q}=180 \mathrm{~L} / \mathrm{s}, \mathrm{Yt}=20 \mathrm{~cm})$. It was noticed that the values of mean velocity $(\mathrm{V}$ at $0.6 \mathrm{y})$ at the cross section at the end of stilling basins were $1.53,0.85,0.95,0.69$ and $0.79 \mathrm{~m} / \mathrm{s}$ for cases A, B, C, D and E respectively. So, case D was the optimum design according to velocity distribution, while case $\mathrm{C}$ was the less efficient design.

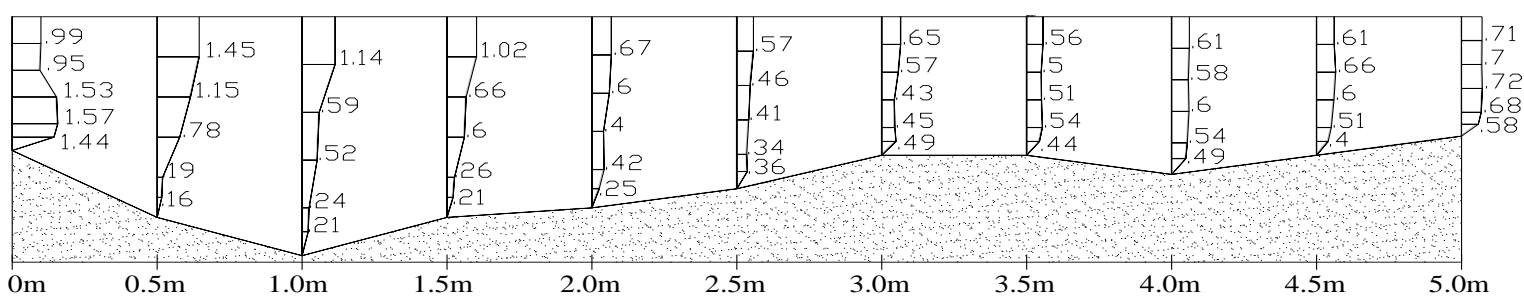

(a), Case A

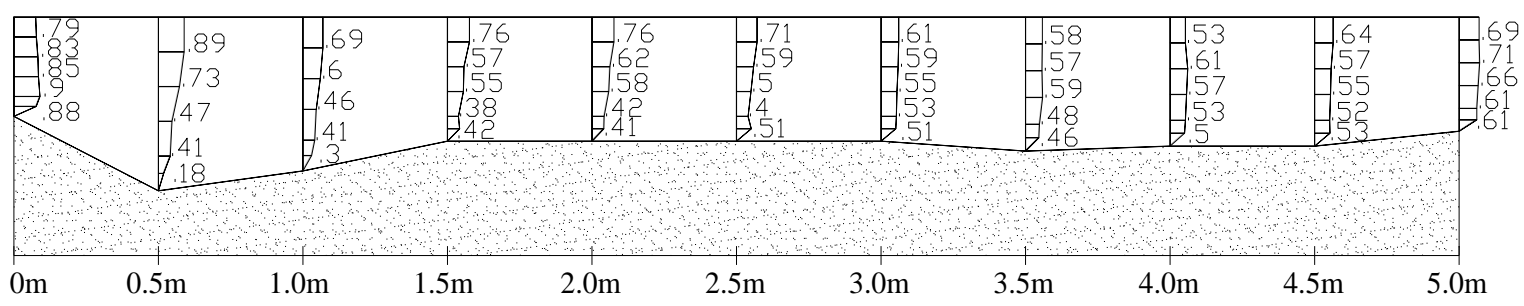

(b), Case B 


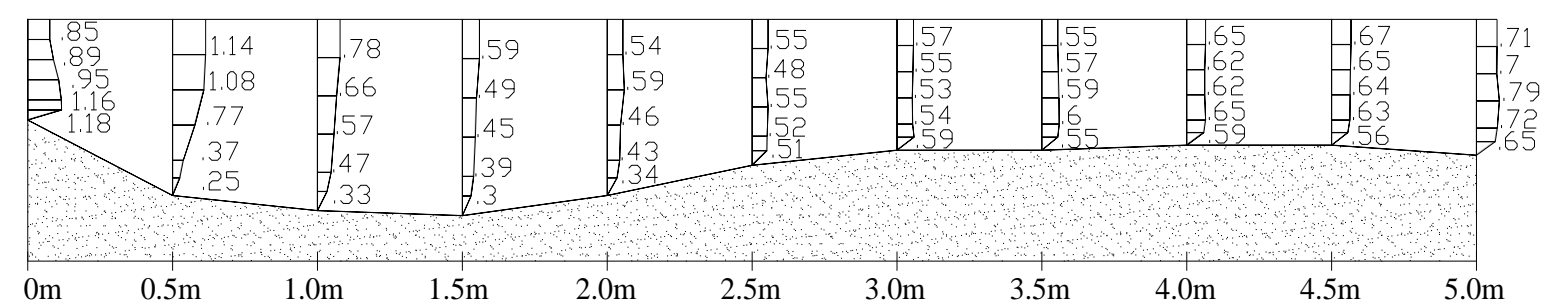

(c), Case C

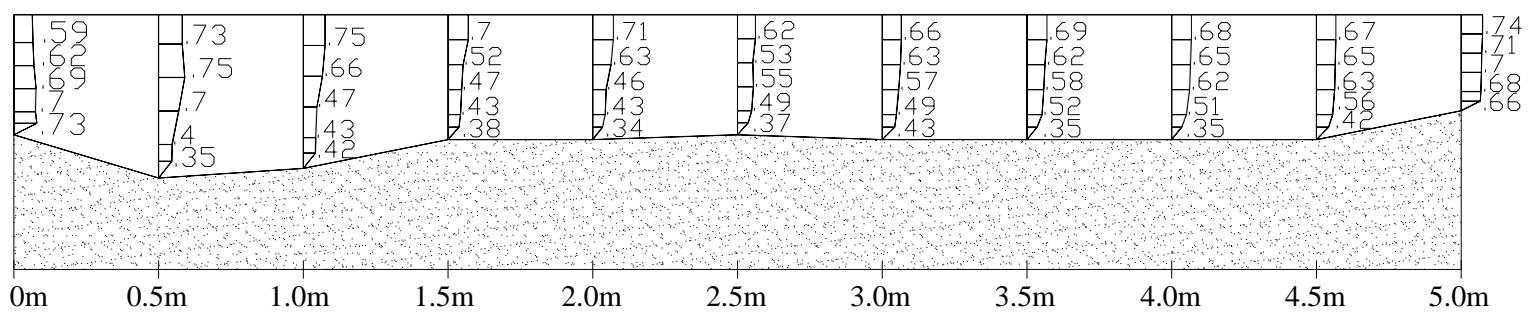

(d), Case D

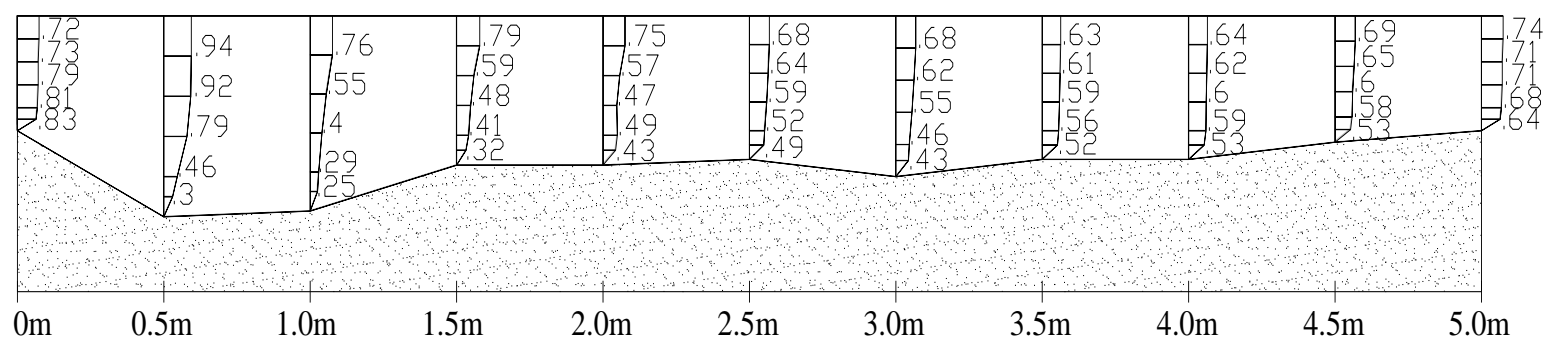

(e), Case E

Figure 4 Velocity Distribution at Different Locations

Table 2 illustrated the velocity average for each point depths for all cross sections for tested design arrangements. The average velocity for cases $\mathrm{B}$ and $\mathrm{D}$ were almost the same for all point depths and it was recorded as the optimal designs according to velocity distribution followed by cases $\mathrm{E}, \mathrm{C}$, and at the last case A without floor jets. The average velocity for all measured points was calculated for all cases and it was found to be $0.624 \mathrm{~m} / \mathrm{s}, 0.58 \mathrm{~m} / \mathrm{s}, 0.62 \mathrm{~m} / \mathrm{s}, 0.572 \mathrm{~m} / \mathrm{s}$, and $0.6 \mathrm{~m} / \mathrm{s}$ for cases A, B, $\mathrm{C}, \mathrm{D}$, and $\mathrm{E}$ respectively.

Table 2 Average Velocities for All Point Depths ( $\left.Q=180 \mathrm{~L} / \mathrm{s}, \mathrm{y}_{\mathrm{t}}=20 \mathrm{~cm}\right)$

\begin{tabular}{|c|c|c|c|c|c|}
\hline Case & $\mathrm{V}(0.2 \mathrm{y})$ & $\mathrm{V}(0.4 \mathrm{y})$ & $\mathrm{V}(0.6 \mathrm{y})$ & $\mathrm{V}(0.8 \mathrm{y})$ & $\mathrm{V}(0.9 \mathrm{y})$ \\
\hline A & 0.82 & 0.67 & 0.65 & 0.52 & 0.46 \\
\hline B & 0.7 & 0.64 & 0.58 & 0.51 & 0.48 \\
\hline C & 0.69 & 0.66 & 0.63 & 0.59 & 0.53 \\
\hline D & 0.69 & 0.63 & 0.59 & 0.51 & 0.44 \\
\hline E & 0.73 & 0.66 & 0.60 & 0.53 & 0.48 \\
\hline
\end{tabular}

The reduction in the mean velocity $\left(\mathrm{V}_{0.6 y}\right)$ for all cases of floor jets with respect to the case A was presented in Table 3 . The reduction percentage of the mean velocity $\left(\mathrm{V}_{0.6 y}\right)$ was calculated based on the average velocity of the velocity profile at the end of stilling basin. The maximum reduction in mean velocity was $61.48 \%$ for case $\mathrm{D}$ for flow condition $\left(\mathrm{Q}=180 \mathrm{~L} / \mathrm{s}, \mathrm{Y}_{\mathrm{t}}=25\right.$ $\mathrm{cm})$, while the minimum percentage of reduction was $6.67 \%$ for case $B$ for flow condition $\left(Q=120 \mathrm{~L} / \mathrm{s}, \mathrm{Y}_{\mathrm{t}}=25 \mathrm{~cm}\right)$. It was illustrated that case $\mathrm{D}$ had maximum reduction in the mean velocity for all flow conditions. 
Table 3 Reduction Percentage of Mean Velocity $\left(\mathrm{V}_{0.6 y}\right)$ Compared to Case (A)

\begin{tabular}{|c|c|c|c|c|c|c|}
\hline Test & $\mathrm{Q}$ & $\mathrm{Y}_{\mathrm{t}}$ & \multicolumn{4}{|c|}{ Percentage Reduction, \% } \\
\cline { 4 - 7 } No. & $\mathrm{L} / \mathrm{s}$ & $\mathrm{cm}$ & Case B & Case C & Case D & Case E \\
\hline 1 & 120 & 20 & 54.00 & 59.00 & 60.00 & 57.00 \\
\hline 2 & 120 & 25 & 6.67 & 15.56 & 40.00 & 8.89 \\
\hline 3 & 120 & 30 & 13.16 & 21.05 & 50.00 & 15.79 \\
\hline 4 & 150 & 20 & 18.75 & 22.50 & 25.00 & 21.25 \\
\hline 5 & 150 & 25 & 39.51 & 41.98 & 41.98 & 39.51 \\
\hline 6 & 150 & 30 & 21.74 & 21.74 & 26.09 & 8.70 \\
\hline 7 & 180 & 20 & 44.44 & 37.91 & 54.90 & 48.37 \\
\hline 8 & 180 & 25 & 55.74 & 53.28 & 61.48 & 53.28 \\
\hline 9 & 180 & 30 & 15.69 & 15.69 & 23.53 & 13.73 \\
\hline
\end{tabular}

The bed configurations downstream stilling basin for all proposed cases at high flow conditions were illustrated in Figure 5. It was noticed that the maximum and minimum scour depths were $27 \mathrm{~cm}$ and $21 \mathrm{~cm}$ for the cases $\mathrm{C}$ and E, respectively.
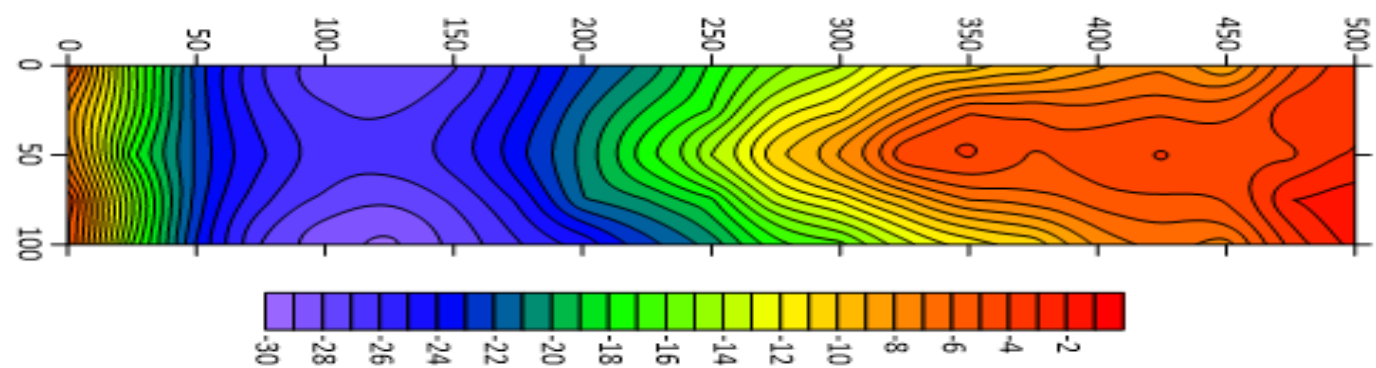

(a), Case A

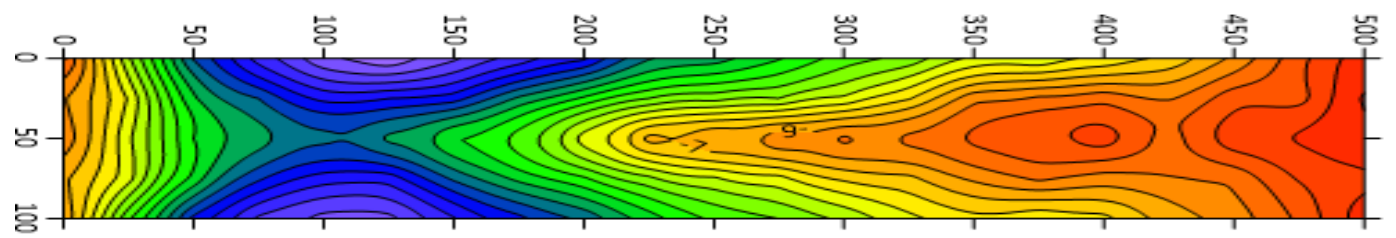

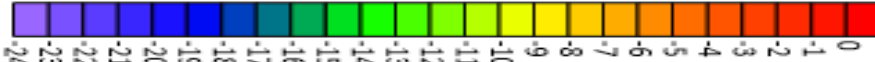

(b), Case B

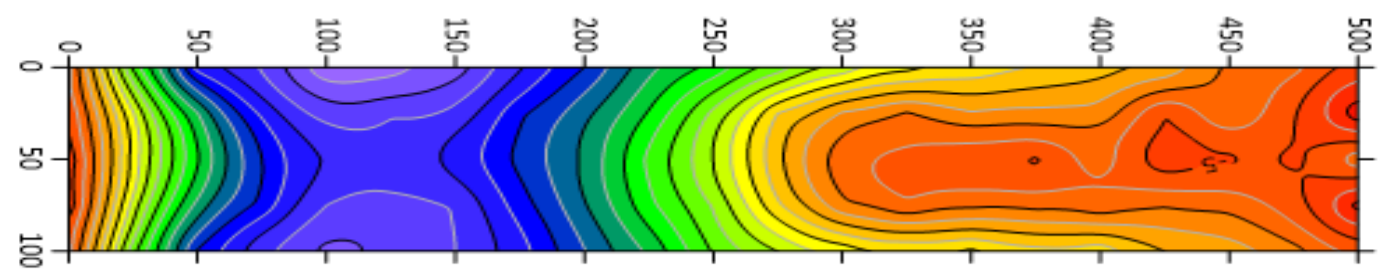

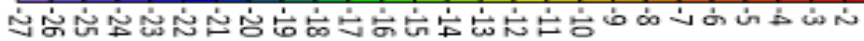

(c), Case C 


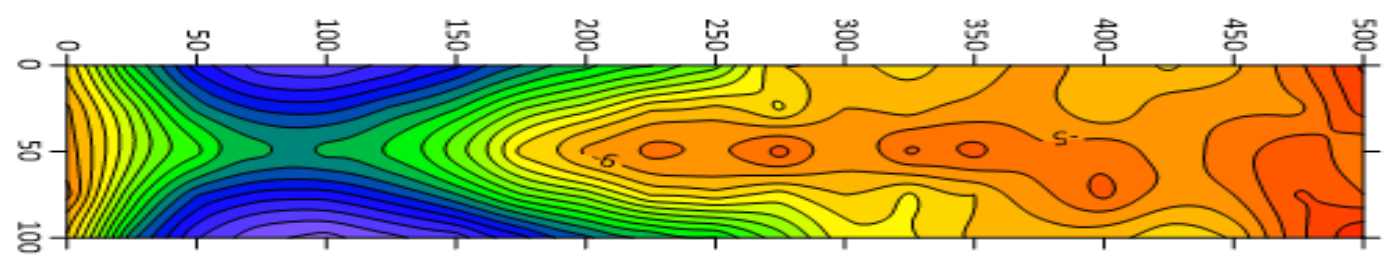

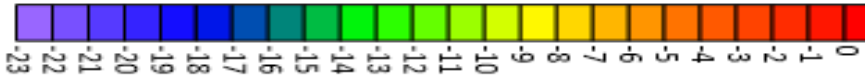

(d), Case D

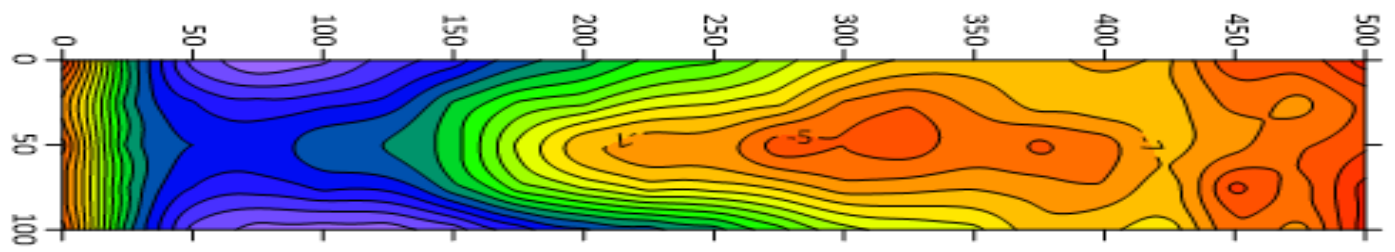

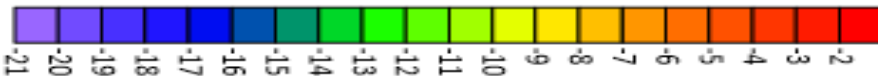

(e), Case E

Figure 5 Bed Morphology Downstream Stilling Basin for Different Cases

A comparison between bed configurations at the centerline of the flume along the tested length of movable bed was shown in Figure 6. The maximum value of $\frac{d s}{y t}=-1.33$ at $25 \%$ from the total length of the sand area was found in case A, followed by case $\mathrm{C}$ with $\frac{d s}{y t}=-1.18$ at $25 \%$ from the total length, then case B with $\frac{d s}{y t}=-0.84$ at $20 \%$ from length, then case $\mathrm{E}$ with $\frac{d s}{y t}=-0.83$ at $15 \%$ from total length. So, the minimum value of $\frac{d s}{y t}=-0.74$ at $15 \%$ from length was that for case D. It was found that case $\mathrm{C}$ had no effect in decreasing scour dimensions compared to case A. That was because the floor jets were found in the location of hydraulic jump area, where the effect of jets was unnoticeable. So, selecting the optimum arrangement would be according to the velocity distribution and the volume of scour.

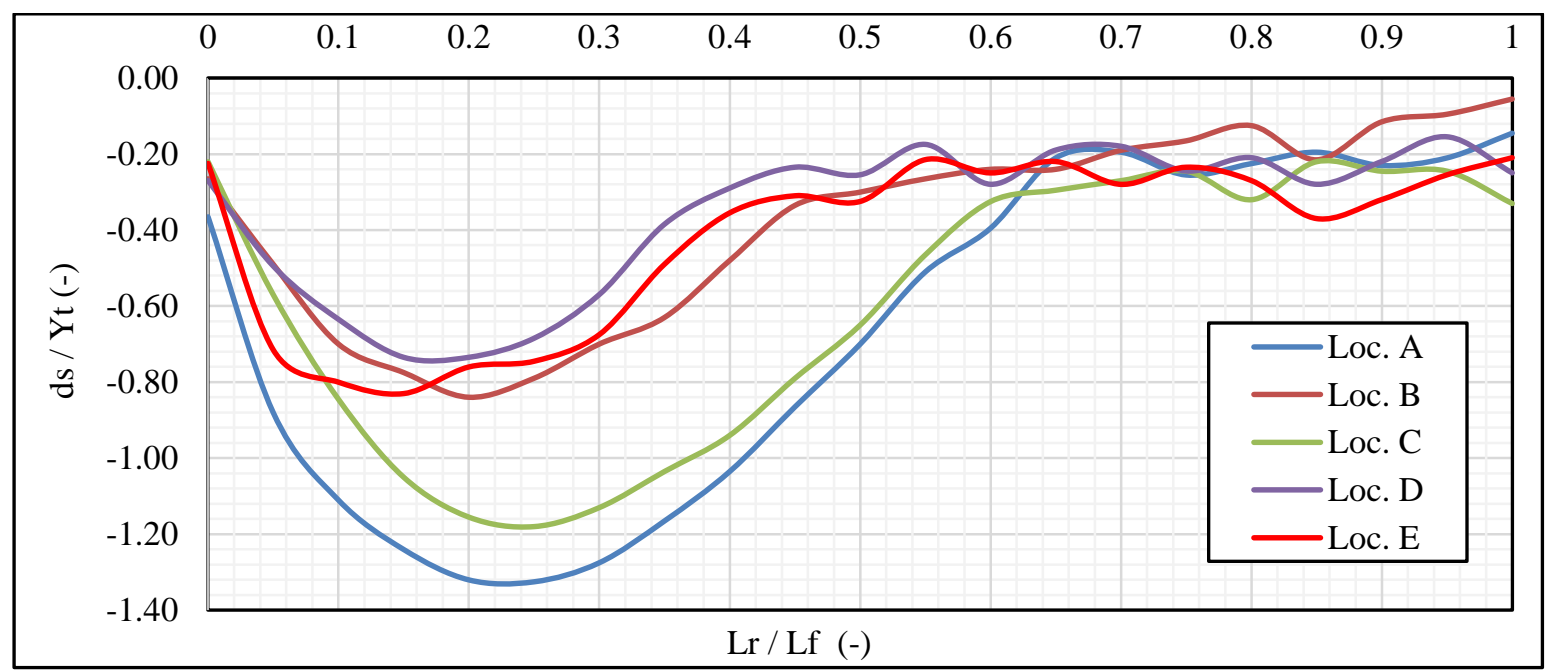

Figure 6 Relations $\left(\mathrm{d}_{\mathrm{s}} / \mathrm{Y}_{\mathrm{t}}\right)$ and $\left(\mathrm{L}_{\mathrm{r}} / \mathrm{L}_{\mathrm{f}}\right)$

Figure 7 illustrated the influence of discharge on the bed configurations under tailwater depth of $20 \mathrm{~cm}$. The maximum and minimum local scour depths for $\mathrm{Q}=120 \mathrm{~L} / \mathrm{s}$ were $15.6 \mathrm{~cm}$ and $6.29 \mathrm{~cm}$. So, case D caused lessening in scour depth by 59.68 $\%$. The maximum and minimum lengths of scour were $2.85 \mathrm{~m}$ and $0.8 \mathrm{~m}$. So, the reduction in scour length was $71.93 \%$. 
For the $\mathrm{Q}=150 \mathrm{~L} / \mathrm{s}$, the maximum and minimum scour depths were $20.35 \mathrm{~cm}$ and $9.2 \mathrm{~cm}$, so the percentage of reduction was $54.79 \%$. The maximum and minimum scour lengths were $3.0 \mathrm{~m}$ and $1.25 \mathrm{~m}$, so case D achieved $58.33 \%$ reduction in scour length.

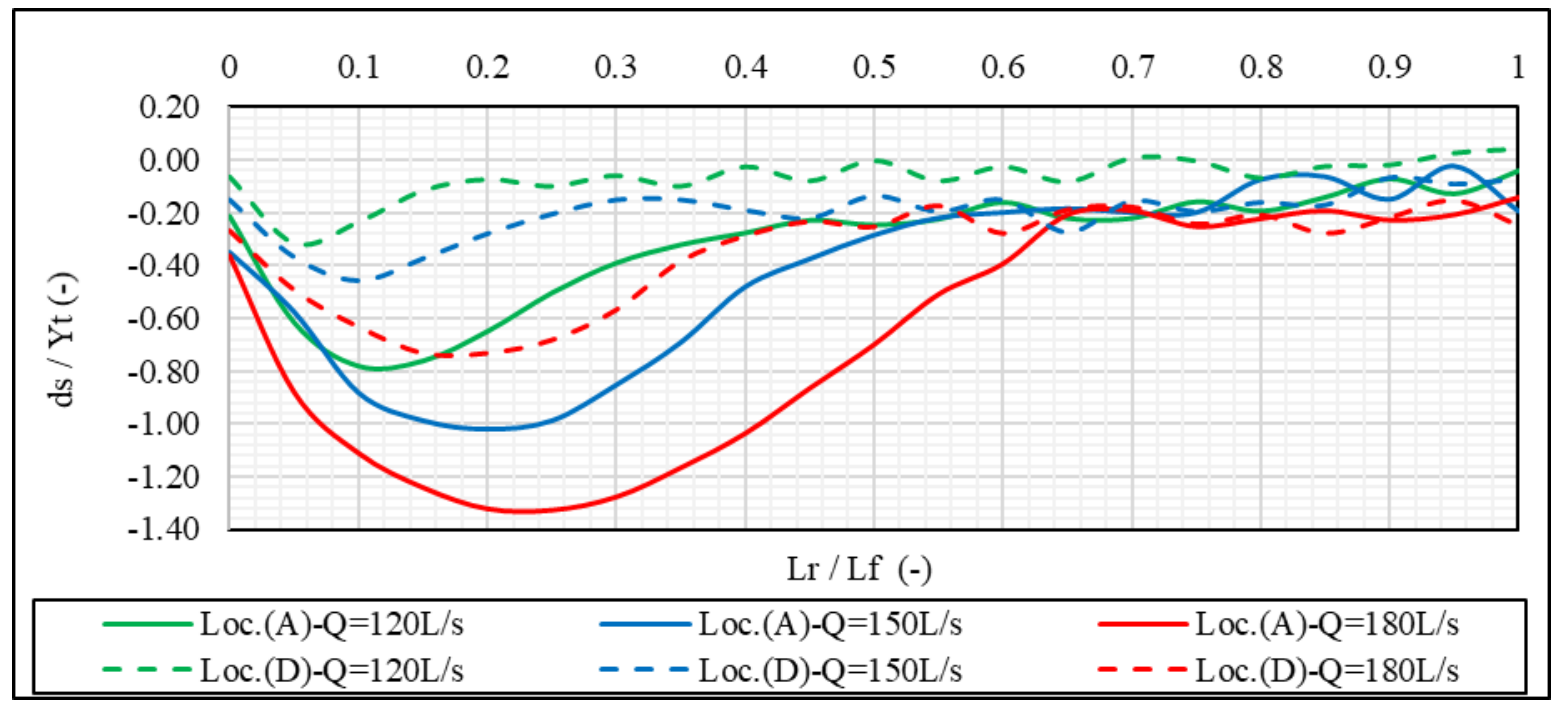

Figure 7 Bed Morphology for Different Discharges, $Y_{t}=20 \mathrm{~cm}$

For critical flow discharge, it was recorded that the maximum and minimum scour depths for cases A and D were $26.5 \mathrm{~cm}$ and $14.7 \mathrm{~cm}$, and scour lengths were $3.25 \mathrm{~m}$ and $2.20 \mathrm{~m}$, so the percentage of reduction in scour depth and length were $44.53 \%$ and $32.31 \%$, respectively.

The influence of tailwater depths on the bed configurations with discharge $180 \mathrm{~L} / \mathrm{s}$ was presented in Figure 8 . It was clearly noticed that the scour characteristics were decreased by the increase of tail water depth $\left(\mathrm{y}_{\mathrm{t}}\right)$. For case A for tailwater depths 20 $\mathrm{cm}$ and $30 \mathrm{~cm}$, the maximum scour depths were $15.6 \mathrm{~cm}$ and $9.35 \mathrm{~cm}$, and scour lengths were $2.85 \mathrm{~m}$ and $0.85 \mathrm{~m}$. So, percentage of reduction in maximum scour depth and length were $40.06 \%$ and $70.18 \%$ respectively. For case D for tailwater depths $20 \mathrm{~cm}$ and $30 \mathrm{~cm}$, the maximum scour depths were $6.29 \mathrm{~cm}$ and $2.23 \mathrm{~cm}$, and scour lengths were $0.8 \mathrm{~m}$ and $0.4 \mathrm{~m}$. So, the reduction percentage in scour depth and length were $64.55 \%$ and $50 \%$ respectively.

Figure 9 illustrated that the maximum percentage of scour volume was $49.8 \%$ for case A, followed by cases C, B and E with values of $44.96 \%, 34.7 \%$ and $34.05 \%$. The minimum percentage of the scour volume was $31.66 \%$ that was recorded for caseD.

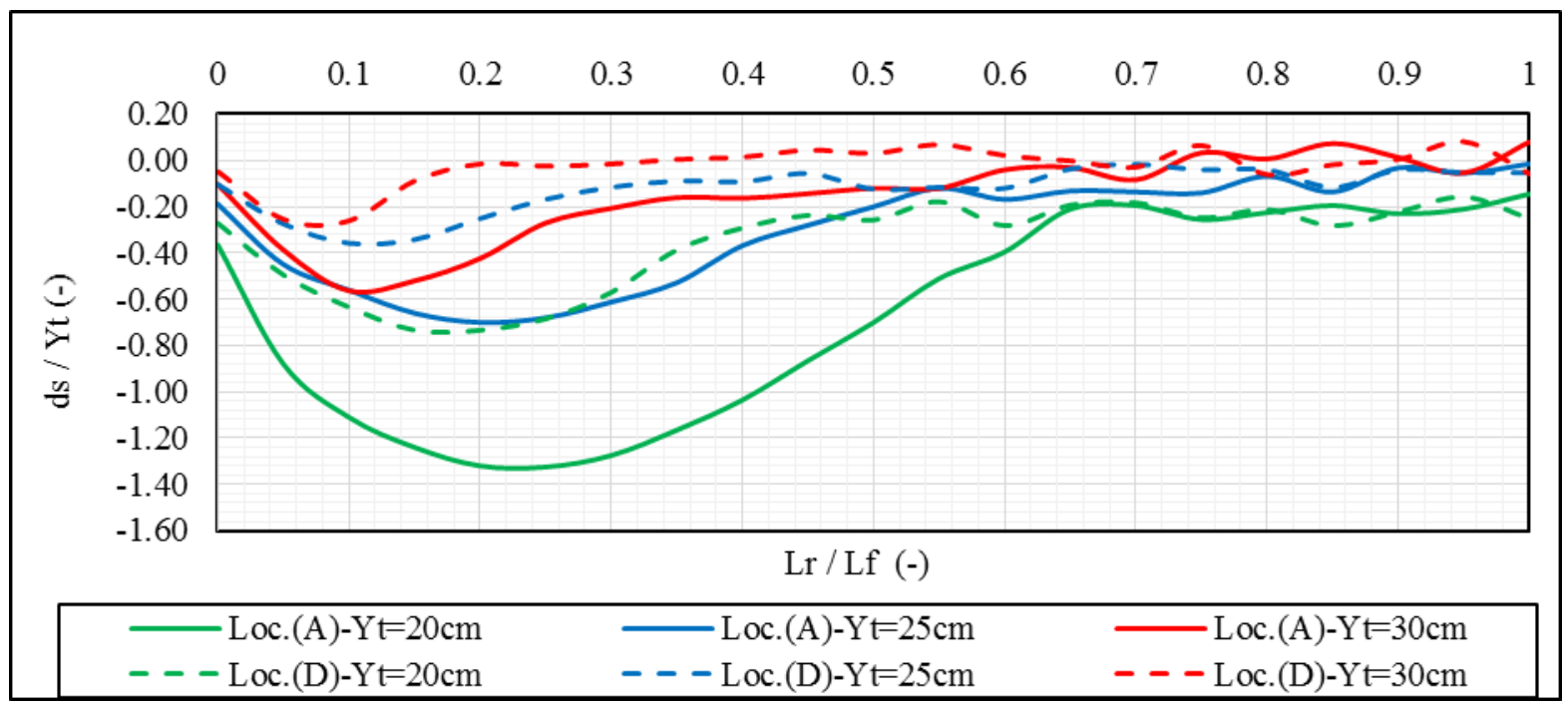

Figure 8 Bed Morphology for Different Tail water Depths, Q=180L/s 


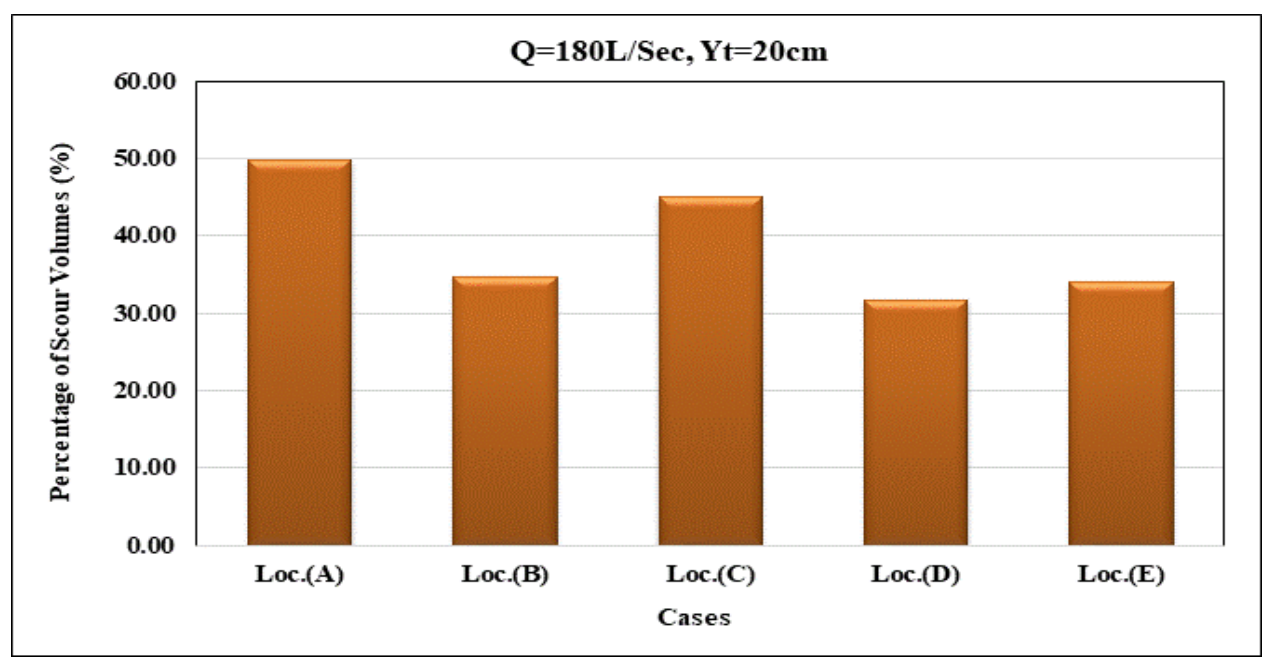

Figure 9 Percentage of Scour Volumes

The influence of cases of floor jet rows on the volume of scour could be illustrated in Table 4 . The maximum reduction in the percentage of scour volume was $75.86 \%$ that was recorded for case $C$ with flow condition $\left(Q=120 \mathrm{~L} / \mathrm{s}, \mathrm{Y}_{\mathrm{t}}=20 \mathrm{~cm}\right)$. The minimum reduction in scour volume was $9.73 \%$ that was recorded for case $\mathrm{C}$ with flow condition $\left(\mathrm{Q}=180 \mathrm{~L} / \mathrm{s}, \mathrm{Y}_{\mathrm{t}}=20 \mathrm{~cm}\right)$.

Table 4 Reduction Percentage of Scour Volumes Compared to Case (A)

\begin{tabular}{|c|c|c|c|c|c|c|}
\hline Test & Q & Yt & \multicolumn{4}{|c|}{ Reduction in $\mathrm{V}_{\text {Scour }}, \%$} \\
\cline { 4 - 7 } No. & Lit/Sec & Cm & Case B & Case C & Case D & Case E \\
\hline 1 & 120 & 20 & 14.32 & 75.86 & 75.04 & 54.70 \\
\hline 2 & 120 & 25 & 35.47 & 62.54 & 50.09 & 42.59 \\
\hline 3 & 120 & 30 & 59.65 & 72.94 & 74.12 & 63.91 \\
\hline 4 & 150 & 20 & 32.49 & 40.97 & 56.72 & 46.46 \\
\hline 5 & 150 & 25 & 47.06 & 58.71 & 62.45 & 68.57 \\
\hline 6 & 150 & 30 & 54.08 & 56.94 & 62.56 & 43.40 \\
\hline 7 & 180 & 20 & 30.32 & 9.73 & 36.43 & 31.62 \\
\hline 8 & 180 & 25 & 37.22 & 55.77 & 54.33 & 55.55 \\
\hline 9 & 180 & 30 & 28.90 & 56.56 & 60.54 & 54.46 \\
\hline
\end{tabular}

\section{Conclusions}

Based on the experimental study to investigate the efficiency of stilling basin using different scenarios floor water jets arrangement. According to the bed topography and the velocity distribution downstream Fayoum type weir, the following conclusion were obtained:

- Case $\mathrm{D}$ was the optimum design according to scour depth and the mean velocity ( $\mathrm{V}$ at $0.6 \mathrm{y}$ ) at first cross section found at the end of stilling basin.

- $\quad$ Case $\mathrm{C}$ had no effect in the bed configuration compared to case $\mathrm{A}$.

- Difference between bed configuration for the cases B, D and E were unnoticeable.

- Relation between discharge and reduction percentage in both scour depth and scour length was inversely proportional for the same tail water depth.

- The relation between tail water depth, scour depth and scour length was inversely proportional.

- Case $\mathrm{D}$ had the minimum scour volume at the critical flow condition $\left(\mathrm{Q}=180 \mathrm{~L} / \mathrm{s}, \mathrm{y}_{\mathrm{t}}=20 \mathrm{~cm}\right)$. 


\section{Acknowledgments}

This research is a part of Ph.D thesis of the last author under supervision of the other authors. All authors are appreciatively acknowledging the Hydraulics Research Institute (HRI), National Water Research Center (NWRC), Ministry of Water Resources and Irrigation (MWRI), Egypt for collaboration and facilitating the physical modeling.

\section{References}

[1] Edward AE. Hydraulic energy dissipators. New York, Toronto,London: Mc-Graw Hill Book Co., Inc.; 1959.

[2] Peterka AJ. Hydraulic design of stilling basin and energy dissipators. Washington, DC: U.S. Dept. of the Interior Bureau of Reclamation; 1978.

[3] Thulfikar Razzak Al-Husseini, Abdul-Sahib T. Al-Madhhachi and Zainab A. Naser (2019): "Laboratory experiments and numerical model of local scour around submerged sharp crested weirs", Journal of King Saud University- Engineering Sciences, Jan.2019.

[4] E.A. Elnikhely (2018): "Investigation and analysis of scour downstream of a spillway", Ain Shams Engineering Journal, Vol. 9, Issue 4, Dec., pp. 2275-2282.

[5] Gamal M. Abdel Aal, M. Sobeah, Esam Helal and M. El-Fooly (2017): "Improving energy dissipation on stepped spillways using breakers", Ain Shams Engineering Journal.

[6] Akram Abbaspour, Sahar Parvini, Ali Hosseinzadeh Dalir (2016): "Effect of buried plates on scour profiles downstream of hydraulic jump in open channels with horizontal and reverse bed slopes", Water Science and Engineering, Vol. 9, Issue 4, Oct., pp. 329-335.

[7] M. M. Ibrahim (2016): "Bed Configurations of Downstream Sharp Crested Weir with Orifices", Journal of Scientific Research \& Reports, Vol. 9, Issue 2, pp. 1-16.

[8] Seungho Hong, Celio Biering, Terry W. Sturm, Kwang Seok Yoon and JuanA. Gonzalez-Castro (2015): " Effect of Submergence and Apron Length on Spillway Scour:Case Study", Journal of water, Vol. 7, Issue 10, 12 Oct., pp.5378-5395.

[9] Mohammad Mahmoud Ibrahim (2015): "Bed profile downstream compound sharp crested V-notch weir", Alexandria Engineering Journal, vol.54, Issue 3, 23April, pp.607-613.

[10] Ahmed Mostafa Ahmed Amin (2015): "Physical model study for mitigating local scour downstream of clear over-fall weirs", Ain Shams Engineering Journal, vol. 6, issue 4, Dec., pp. 1143-1150.

[11] Hossam Mohamed Ali, Mohamed Mohamed El Gendy, Ahmed Mohamed Hassan Mirdan, Abdel Azim Mohamed Ali and Fahmy Salah Fahmy Abdelhaleem (2014): " Minimizing downstream scour due to submerged hydraulic jump using corrugated aprons", Ain Shams Engineering Journal, Vol. 5, Issue4, Dec., pp. 1059-1069.

[12] Esam El-Deen Yousry El-Azab Helal (2014): "Minimizing scour downstream of hydraulic structures using single line of floor water jets", Ain Shams Engineering Journal, Vol. 5, Issue1, Mar., pp. 17-28.

[13] Fahmy Salah Fahmy Abdelhaleem (2013): "Effect of semi-circular baffle blocks on local scour downstream clear-overfall weirs", Ain Shams Engineering Journal, Vol. 4, Issue 4, Dec., pp. 675-684.

[14] M.C. Tuna and M.E. Emiroglu (2011): " Scour profiles at downstream of cascades", Scientia Iranica, Vol. 18, Issue 3, Jun., pp. 338-347.

[15] Dehghani, Amir. Ahmad, Bashiri, Hamid, Meshkati Shahmirzadi, Mohamad Ebrahim and Ahadpour, Asgar (2009): "Experimental Investigation of Scouring in Downstream of Combined flow over Weirs and below Gates", 33rd IAHR Congress: Water Engineering for a Sustainable Environment. 